\title{
Hasil Uji Coba Video Pembelajaran Mata Kuliah Kultur Jaringan Berbasis Masalah pada Dosen dan Mahasiswa Program Studi Pendidikan Biologi UMTS
}

\author{
Melvariani Syari Batubara \\ Program Studi Pendidikan Biologi FKIP, Universitas Muhammadiyah Tapanuli Selatan \\ Email: melva_smile@yahoo.com
}

\begin{abstract}
Abstrak: Penelitian ini bertujuan untuk mengembangkan media video pembelajaran kultur jaringan berbasis masalah. Penelitian pengembangan ini menggunakan model Borg dan Gall melalui 7 tahapan yaitu: (1) Pengumpulan data penelitian berupa nilai hasil belajar mahasiswa mata kuliah kultur jaringan, observasi, dan wawancara kepada mahasiswa yang mengikuti mata kuliah kultur jaringan dan dosen pengampu mata kuliah kultur jaringan, (2) Perencanaan berupa membuat sintak pembelajaran berbasis masalah (PBL) dan membuat skenario setiap materi kultur jaringan, (3) Pengembangan produk awal berupa video pembelajaran kultur jaringan berbasis masalah, (4) Uji coba lapangan produk utama berupa uji teman sejawat, perorangan dan kelompok kecil oleh mahasiswa yang mengikuti mata kuliah kultur jaringan, (5) Revisi produk uji coba lapangan utama, (6) Uji coba lapangan skala luas berupa uji coba lapangan terbatas oleh mahasiswa yang mengikuti mata kuliah kultur jaringan, (7) Revisi produk final hasil uji coba lapangan skala luas. Pengumpulan data dilakukan dengan menggunakan angket. Data dianalisis dengan menggunakan teknik analisis deskriptif. Dari hasil penilaian terhadap video pembelajaran kultur jaringan berbasis masalah yang telah dikembangkan dinilai "layak" digunakan dengan persentase rata-rata skor 76,7\% oleh teman sejawat dosen. Hasil tanggapan mahasiswa dinilai "layak" digunakan, melalui uji coba perorangan dengan persentase rata-rata skor $75,6 \%$, uji coba kelompok kecil $73,8 \%$, dan uji coba lapangan terbatas $82 \%$. Media video pembelajaran kultur jaringan berbasis masalah dikategorikan baik dan "layak" digunakan pada perkuliahan kultur jaringan.
\end{abstract}

Kata kunci: Video Pembelajaran, Kultur Jaringan, Pembelajaran Berbasis Masalah (PBL)

\section{PENDAHULUAN}

Cabang ilmu terapan bioteknologi, yaitu kultur jaringan. Kultur jaringan dapat dimaknai sebagai budidaya jaringan/sel tanaman menjadi tanaman utuh yang kecil yang mempunyai sifat yang sama dengan induknya (Harahap, 2011). Mata kuliah kultur jaringan tergolong ke dalam kelompok bidang kajian bioteknologi yang terdiri dari banyaknya proses dan perhitungan. Materi yang diberikan pada mata kuliah ini adalah pengenalan kultur jaringan tanaman, pengenalan laboratorium kultur jaringan, sterilisasi alat dan bahan, pembuatan media kultur jaringan Murashige and Skoog (MS), perbanyakan tanaman secara in vitro, induksi kalus, dan sterilisasi dan penanaman dari eksplan lapang. Pada kenyataannya banyak materi mata kuliah kultur jaringan ini tergolong baru, yang terkesan monoton, dan bersifat abstrak bagi mahasiswa yang mengikuti mata kuliah tersebut. Sehingga untuk mengatasi masalah tersebut dibutuhkan alat bantu agar mempermudah mahasiswa memahami materi pada mata kuliah kultur jaringan. Saat ini, belum ada media pembelajaran yang efektif digunakan untuk membantu pemahaman mahasiswa terhadap materi pada mata kuliah kultur jaringan, sehingga perlu dikembangkan media pembelajaran yang baik berupa video pembelajaran.

Wawancara kepada mahasiswa yang mengikuti mata kuliah kultur jaringan di Program Studi Pendidikan Biologi, Universitas Muhammadiyah Tapanuli Selatan, diperoleh informasi bahwa dosen pengampu mata kuliah belum sepenuhnya menggunakan media video pembelajaran di dalam proses pembelajaran kultur jaringan. Media yang digunakan pada saat pembelajaran masih biasa dan terbatas berupa media visual dengan menggunakan LCD, sehingga diperlukan pengembangan media dalam bentuk audio-visual yaitu berupa video pembelajaran yang dapat meningkatkan minat belajar, kemampuan berpikir kritis, hasil belajar dan pemahaman mahasiswa terhadap mata kuliah kultur jaringan. Selain itu, dari observasi di lapangan, juga didapatkan informasi bahwa laboratorium kultur jaringan di Universitas Muhammadiyah Tapanuli Selatan juga belum ada, pada saat ini masih hanya sebatas perkuliahan saja, sehingga diperlukan penggunaan video pembelajaran yang dapat menggantikan fungsi laboratorium kultur jaringan. 
Hasil studi awal yang dilakukan pada dosen pengampu mata kuliah kultur jaringan, menunjukkan bahwa hasil belajar mahasiswa Program Studi Pendidikan Biologi, Universitas Muhammadiyah Tapanuli Selatan Tahun Ajaran 2014/2015, yang belum menggunakan video pembelajaran di dalam proses pembelajaran cukup rendah dibandingkan dengan yang sesekali menggunakan video pembelajaran, yang dibuktikan dari perolehan nilai ujian akhir semester dari dua kelas (ada kelas yang sesekali menggunakan video pembelajaran di dalam proses pembelajarannya dan ada kelas yang belum sama sekali menggunakan video pembelajaran di dalam proses pembelajarannya). Nilai rata-rata dari ujian final mahasiswa yang belum menggunakan video pembelajaran di dalam proses pembelajaran, masih belum bisa mendapatkan nilai B (70-79).

Rendahnya hasil belajar mahasiswa yang sama sekali belum menggunakan video pembelajaran di dalam proses pembelajarannya dapat disebabkan oleh kurang tepatnya media pembelajaran yang digunakan atau diimplementasikan, pembelajaran berpusat pada dosen, mahasiswa kurang terlibat aktif dalam proses pembelajaran untuk membangun dan menemukan sendiri pengetahuannya, sehingga mahasiswa hanya menghafal fakta-fakta dari buku.

Media video adalah segala sesuatu yang memungkinkan sinyal radio dapat dikombinasikan dengan gambar bergerak secara sekuensial (Daryanto, 2012). Program video dapat dimanfaatkan dalam program pembelajaran karena dapat memberikan pengalaman yang tidak terduga kepada siswa. Selain itu, program video dapat dikombinasikan dengan animasi dan pengaturan kecepatan untuk mendemonstrasikan perubahan dari waktu ke waktu. Kemampuan video dalam memvisualisasikan materi terutama efektif untuk membantu menyampaikan materi yang bersifat dinamis. Materi yang memerlukan visualisasi seperti mendemonstrasikan hal-hal seperti gerakan motorik tertentu, ekspresi wajah, ataupun suasana lingkungan tertentu melalui pemanfaatan teknologi video dapat disajikan dengan lebih menarik dan kompatibel.

Penelitian tentang video pembelajaran ini penting karena, sudah ada penelitian tentang video pembelajaran tapi belum berbasis masalah. Selain itu juga, video pembelajaran juga sangat penting untuk digunakan sebagai sumber belajar. Dari hasil penelitian Pujadi dan Harisno (2013), dapat dihasilkan bahwa modul aplikasi model perangkat ajar berbasis animasi dan video tutorial dapat mendukung siswa dalam memperoleh kelengkapan data yang dibutuhkan dan cukup membantu siswa dalam memahami materi dengan lebih mudah.

Dengan kata lain dalam penelitian ini akan dikembangkan video pembelajaran berbasis masalah. Video pembelajaran dengan berbasis masalah memegang peran yang cukup signifikan karena berdasarkan hasil penelitian dari Rasim, Setiawan, dan Rahman (2008), dapat dihasilkan bahwa metode pembelajaran berbasis komputer yang dikembangkan dapat memberikan visualisasi materi abstrak, membantu mahasiswa belajar tanpa dibatasi ruang dan waktu, dapat menggunakan berbagai media pembelajaran sehingga materi presentasi lebih interaktif, membantu mahasiswa dalam memahami materi yang lebih dalam dan penggunaan gabungan media pembelajaran akan meningkatkan performance materi presentasi.

Dalam penelitian ini akan dikembangkan video pembelajaran berbasis masalah tentang materi kultur jaringan. Beberapa alasan kenapa materi kultur jaringan ini dipilih sebagai tema dalam pengembangan media video pembelajaran berbasis masalah ini, antara lain, sumber media pembelajaran terutama video pembelajaran berbasis masalah tentang materi kultur jaringan belum ada. Berdasarkan hasil penelitian dari Nurcahyo (2004) dapat dihasilkan bahwa proses dan produk penelitian dapat digunakan sebagai media pembelajaran materi kultur sel hewan pada matakuliah bioteknologi. Media pembelajaran materi kultur sel hewan ini mempermudah mahasiswa memahami substansi bioteknologi yang bersifat abstrak, memiliki daya tarik untuk dipelajari, serta dapat memotivasi mahasiswa untuk lebih memahami secara lebih dalam materi bioteknologi. Dari hasil penelitian memperlihatkan bahwa sangat penting untuk mengembangkan media pembelajaran pada materi kultur jaringan tanaman yang berbasis masalah.

\section{METODE PENELITIAN}

Subjek penelitian adalah mahasiswa semester VI Program Studi Pendidikan Biologi, Fakultas Keguruan dan Ilmu Pendidikan, Universitas Muhammadiyah Tapanuli Selatan. Penelitian ini menggunakan pendekatan penelitian pengembangan, karena dalam penelitian ini ingin dihasilkan sebuah produk melalui hasil pengembangan. Data yang diperoleh dalam penelitian ini adalah data 
kualitatif yang diperoleh dari jawaban angket yang diisi oleh mahasiswa, teman sejawat, dan tim ahli.

Langkah-langkah penelitian $\mathrm{R}$ \& $\mathrm{D}$ yang dikemukan Borg dan Gall adalah: (1) Research and Information colletion (penelitian dan pengumpulan data), meliputi pengumpulan data awal berupa nilai hasil belajar mahasiswa mata kuliah kultur jaringan, analisis observasi dan wawancara kepada mahasiswa yang mengikuti mata kuliah kultur jaringan dan dosen pengampu mata kuliah kultur jaringan di Universitas Muhammadiyah Tapanuli Selatan Tahun Ajaran 2014/2015; (2) Planning (perencanaan), meliputi membuat rancangan pembelajaran yaitu pembelajaran berbasis masalah berdasarkan stimulasi dengan sintak yaitu : Memberikan orientasi tentang permasalahannya kepada peserta didik, Mengorganisasikan peserta didik untuk meneliti, Membantu investigasi mandiri dan kelompok, Mengembangkan dan mempresentasikan artefak dan exhibit, serta Menganalisis dan mengevaluasi proses mengatasi masalah. Dan membuat storyboard atau skenario setiap materi yaitu : Pengenalan Kultur Jaringan Tanaman, Pengenalan Laboratorium Kultur Jaringan, Sterilisasi Alat dan Bahan, Pembuatan Media Kultur Jaringan Murashige and Skoog (MS), Perbanyakan Tanaman secara In Vitro, Induksi Kalus, serta Sterilisasi dan Penanaman dari Eksplan Lapang; (3) Develop Preliminary form of Product (pengembangan draft produk awal), meliputi membuat produk awal berupa video pembelajaran berdasarkan data perencanaan dan storyboard atau skenario setiap materi yaitu: Pengenalan Kultur Jaringan Tanaman, Pengenalan Laboratorium Kultur Jaringan, Sterilisasi Alat dan Bahan, Pembuatan Media Kultur Jaringan Murashige and Skoog (MS), Perbanyakan Tanaman secara In Vitro, Induksi Kalus, serta Sterilisasi dan Penanaman dari Eksplan Lapang; (4) Preliminary Field Testing (uji coba lapangan awal), meliputi uji ahli materi kultur jaringan, uji keterbacaan, uji kelayakan oleh ahli media pembelajaran, uji ahli pembelajaran berbasis masalah (PBL), dan oleh teman sejawat; (5) Main Product Revision (revisi hasil uji coba), meliputi melakukan revisi berdasarkan kritik dan saran yang diberikan oleh ahli materi kultur jaringan, ahli media pembelajaran, ahli pembelajaran berbasis masalah (PBL), dan oleh teman sejawat; (6) Main Field Testing (uji lapangan produk utama), meliputi uji terbatas pada 2 orang mahasiswa yang mengikuti mata kuliah kultur jaringan di Universitas Muhammadiyah Tapanuli Selatan dan uji kelompok kecil pada 4 orang mahasiswa; (7) Operational Product Revision (revisi produk), meliputi melakukan revisi berdasarkan kritik dan saran yang diberikan oleh mahasiswa yang mengikuti uji coba perorangan dan uji coba kelompok kecil video pembelajaran berbasis masalah; (8) Operational Field Testing (uji coba lapangan skala luas/uji kelayakan), meliputi uji lapangan pada 22 orang mahasiswa yang mengikuti mata kuliah kultur jaringan di Universitas Muhammadiyah Tapanuli Selatan; (9) Final Product Revision (revisi produk final), meliputi melakukan revisi berdasarkan kritik dan saran yang diberikan oleh mahasiswa yang mengikuti uji coba lapangan terbatas video pembelajaran berbasis masalah; (10) Disemination and Implementasi (Desiminasi dan implementasi), meliputi penyebarluasan video pembelajaran mata kuliah kultur jaringan berbasis masalah.

Penelitian pengembangan ini, menggunakan pendekatan kualitatif, dalam mengumpulkan data, peneliti menggunakan metode validasi oleh ahli media pembelajaran, materi kultur jaringan, ahli pembelajaran berbasis masalah (PBL), dan oleh teman sejawat, wawancara, dokumentasi sebagai data awal, dan kuisioner sebagai uji coba media oleh mahasiswa baik secara perorangan atau uji coba secara kelompok kecil, dan uji coba lapangan terbatas.

Bahan dokumen yang dipelajari peneliti dalam tahap awal mencakup ketersediaan perangkat pembelajaran, yaitu silabus dan satuan acara perkuliahan, modul, bahan ajar yang ada dan media yang digunakan. Sedangkan dokumen yang diperoleh pada saat uji coba produk mencakup hasil belajar mahasiswa, foto-foto dan rekaman unjuk kerja mahasiswa saat evaluasi.

Analisis data dalam penelitian ini adalah deskriptif. Data yang diperoleh dianalisis dalam bentuk Skala Likert yang telah diberi skor 1 - 5 . Kemudian data dianalisis dengan menggunakan statistik deskriptif (skor rata-rata dan persentase), yaitu menghitung persentase indikator penggunaan video pembelajaran yang telah dikembangkan. Perhitungan data hasil penelitian menggunakan rumus di atas akan menghasilkan angka dalam bentuk persen. Klasifikasi skor tersebut selanjutnya diubah menjadi klasifikasi dalam bentuk persentase, kemudian ditafsirkan dengan kalimat kualitatif. 


\section{HASIL DAN PEMBAHASAN}

\section{Hasil}

\section{Penilaian Dosen Terhadap Video} Pembelajaran

Penilaian dosen terhadap video pembelajaran kultur jaringan berbasis masalah yang telah dikembangkan dilakukan oleh Nurmaini Ginting, M. Si. dan Yusni Atifah Pulungan, M. Si. Keduanya adalah Dosen Program Studi Pendidikan Biologi Universitas Muhammadiyah Tapanuli Selatan. Tujuan dari penilaian ini adalah untuk memperoleh komentar dan saran untuk meningkatkan kualitas video pembelajaran yang telah dikembangkan

Berdasarkan hasil penilaian uji coba teman sejawat yang telah dilakukan oleh Dosen Program Studi Pendidikan Biologi UMTS sebanyak 2 orang, maka diperoleh hasil jumlah persentase rata-rata skor adalah $76,7 \%$ termasuk dalam kategori "layak". Hasil analisis penilaian menurut dosen terhadap masing-masing aspek secara keseluruhan, dapat dilihat pada Gambar 1 berikut ini:

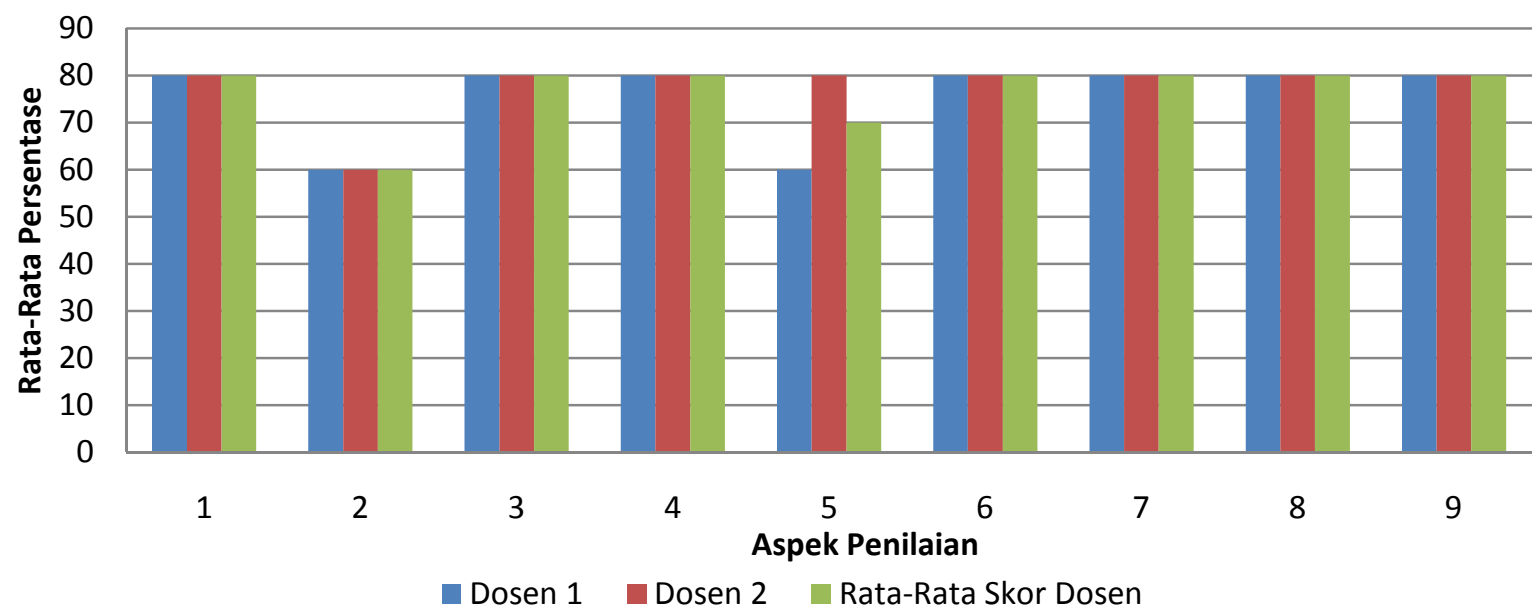

Gambar 1. Penilaian Terhadap Masing-Masing Aspek oleh Dosen

\section{Uji Coba Perorangan}

Berdasarkan hasil penilaian yang telah dilakukan pada uji coba perorangan oleh 2 orang mahasiswa semester VI Program Studi Pendidikan Biologi Universitas Muhammadiyah Tapanuli Selatan Padangsidimpuan, maka diperoleh hasil jumlah persentase rata-rata skor adalah $75,6 \%$ termasuk dalam kategori "layak". Hasil analisis penilaian menurut mahasiswa pada uji coba perorangan terhadap masing-masing aspek secara keseluruhan, dapat dilihat pada Gambar 2 berikut ini:

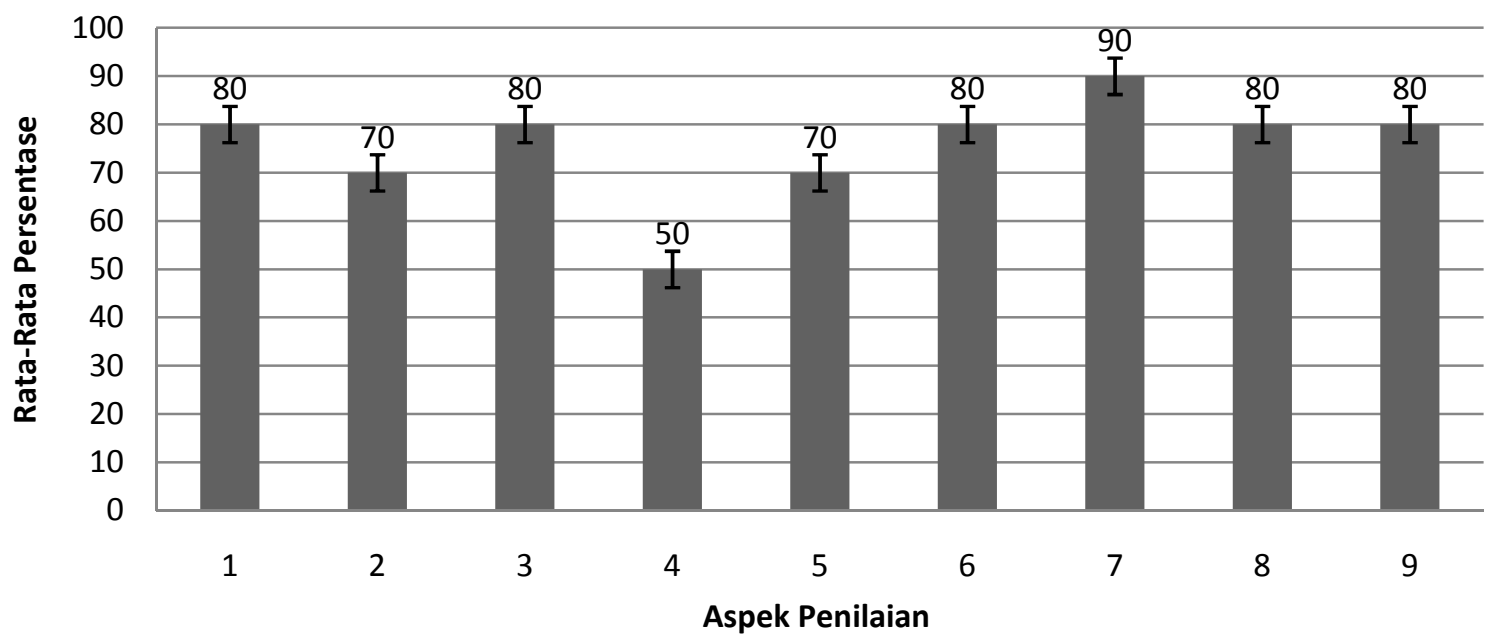

Gambar 2. Penilaian Terhadap Masing-Masing Aspek oleh Mahasiswa pada Uji Coba Perorangan 


\section{Uji Coba Kelompok Kecil}

Berdasarkan hasil penilaian yang telah dilakukan pada uji coba kelompok kecil oleh 4 orang mahasiswa mahasiswa semester VI Program Studi Pendidikan Biologi Universitas Muhammadiyah Tapanuli Selatan Padang Sidimpuan, maka diperoleh hasil jumlah persentase rata-rata skor adalah $73,8 \%$ termasuk dalam kategori "cukup layak". Hasil analisis penilaian menurut mahasiswa pada uji coba kelompok kecil terhadap masing-masing aspek secara keseluruhan, dapat dilihat pada Gambar 3 berikut ini:

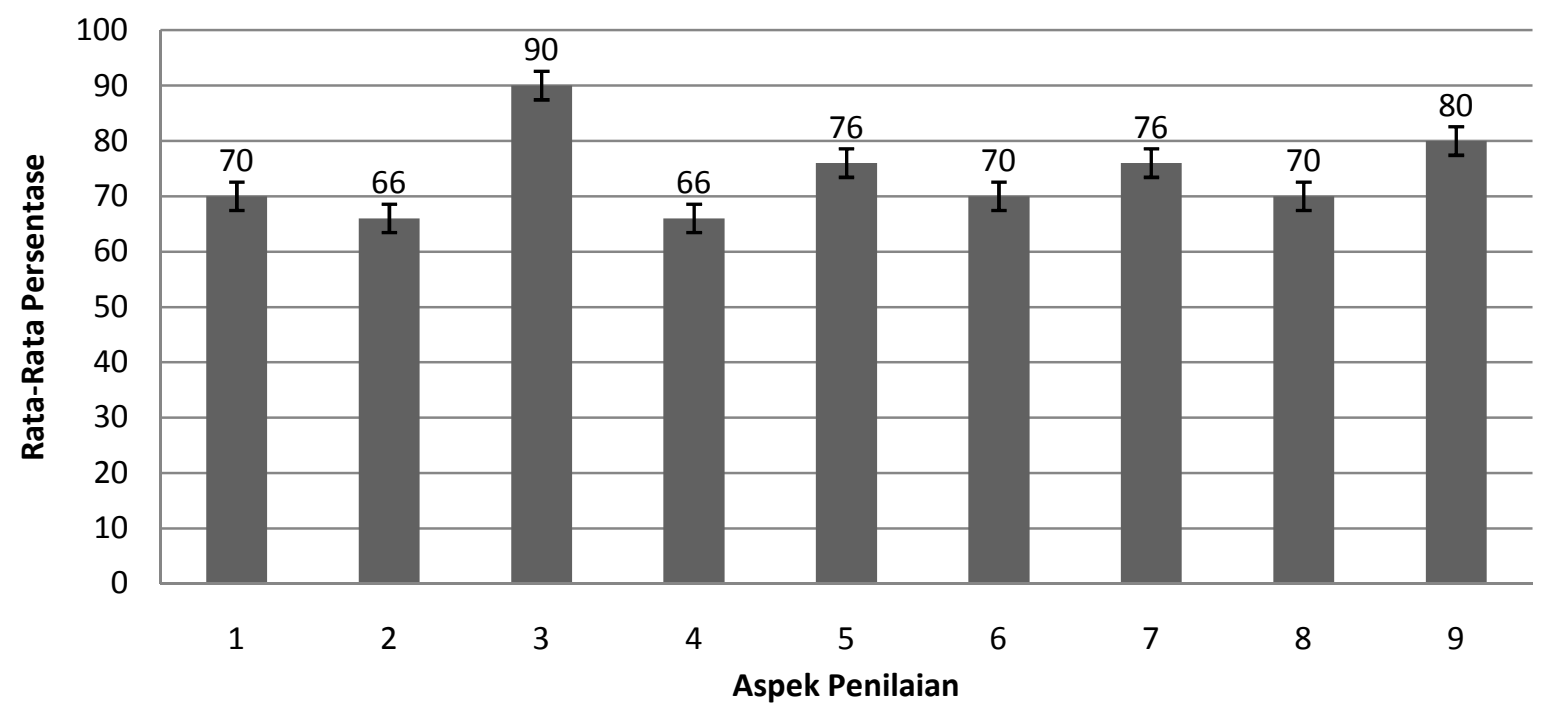

Gambar 3. Penilaian Terhadap Masing-Masing Aspek oleh Mahasiswa pada Uji Coba Kelompok Kecil

\section{Uji Coba Lapangan Terbatas}

Berdasarkan hasil penilaian yang telah dilakukan pada uji coba lapangan terbatas oleh 22 orang mahasiswa mahasiswa semester VI Program Studi Pendidikan Biologi Universitas Muhammadiyah Tapanuli Selatan Padang Sidimpuan, maka diperoleh hasil jumlah persentase rata-rata skor adalah $82 \%$ termasuk dalam kategori "layak". Hasil analisis penilaian menurut mahasiswa pada uji coba lapangan terbatas terhadap masing-masing aspek secara keseluruhan, dapat dilihat pada Gambar 4 berikut ini:

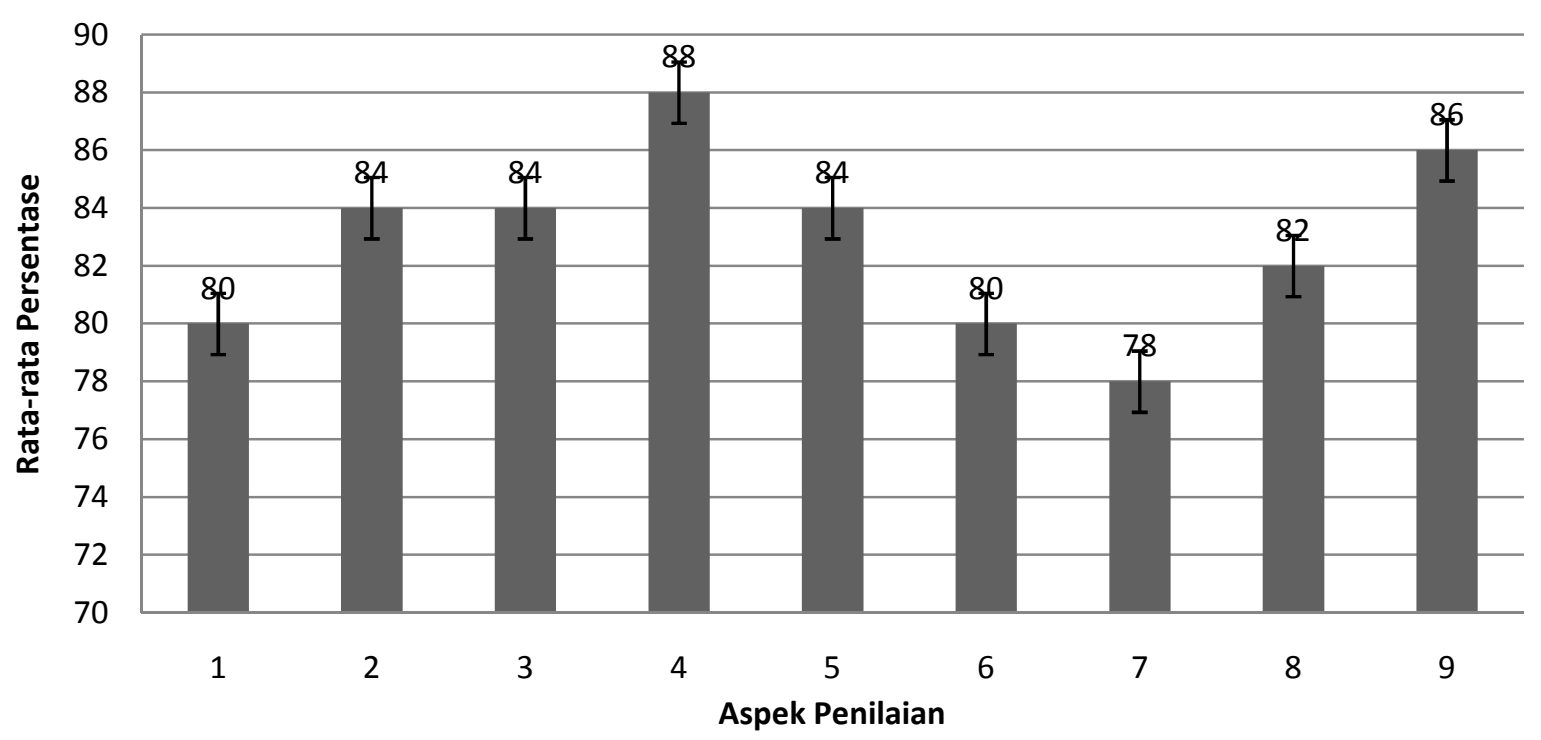

Gambar 4. Penilaian Terhadap Masing-Masing Aspek oleh Mahasiswa pada Uji Coba Kelompok Besar 
Hasil penilaian dan uji coba pada seluruh mahasiswa semester VI Program Studi Pendidikan Biologi Universitas Muhammadiyah Tapanuli Selatan Padang Sidimpuan yang menjadi sampel penelitian, maka dapat disimpulkan bahwa pengembangan video pembelajaran kultur jaringan berbasis masalah dinyatakan "layak" secara keseluruhan.

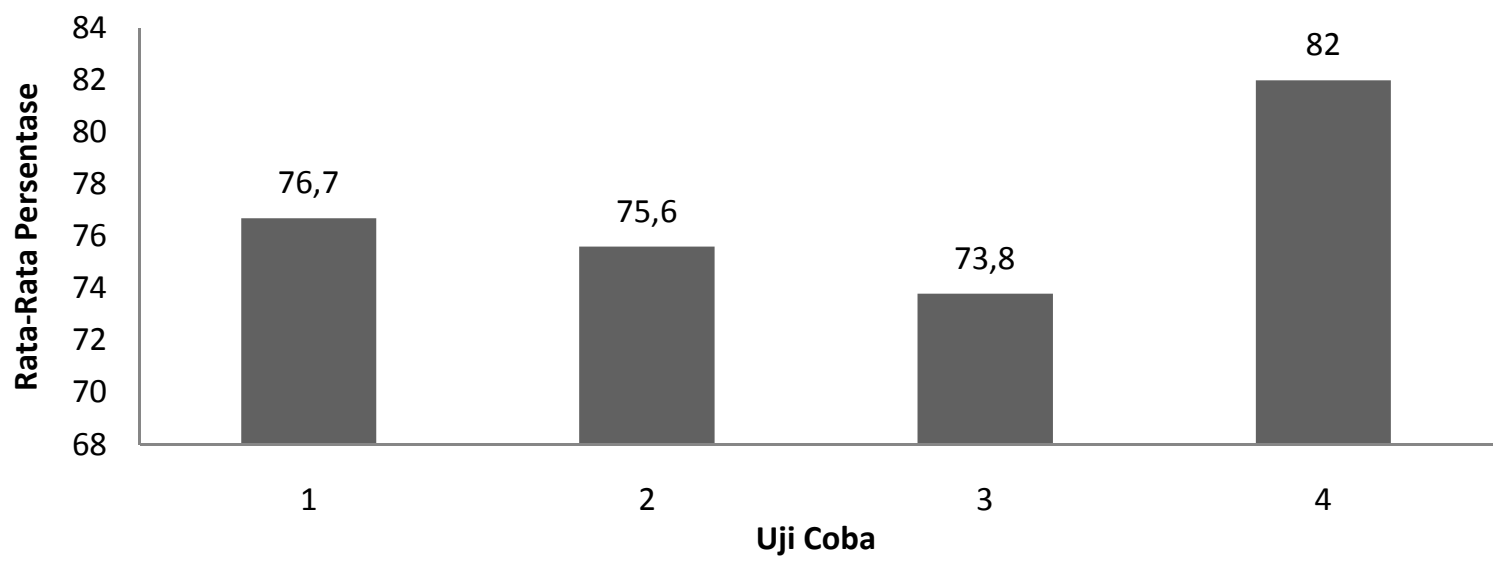

Gambar 5. Perbandingan Hasil Uji Coba oleh Dosen dan Mahasiswa Terhadap Video Pembelajaran Kultur Jaringan Berbasis Masalah

\section{PEMBAHASAN}

Berdasarkan hasil penelitian ditemukan bahwa produk video pembelajaran kultur jaringan berbasis masalah berdasarkan penilaian pada uji coba rekan sejawat dosen, uji coba perorangan, uji coba kelompok kecil, dan uji coba lapangan terbatas oleh mahasiswa bahwa termasuk dalam kategori baik dan "layak".

Hasil penelitian oleh Batubara (2016) pada mahasiswa Program Studi Pendidikan Biologi, Universitas Muhammadiyah Tapanuli Selatan, menunjukkan bahwa hasil penilaian terhadap video pembelajaran kultur jaringan berbasis masalah yang telah dikembangkan dinilai baik dan "layak" digunakan dengan persentase ratarata skor $84 \%$ oleh ahli materi kultur jaringan, $80 \%$ oleh ahli desain video pembelajaran, dan $85 \%$ oleh ahli pembelajaran berbasis masalah (PBL).

Hasil penelitian Hasruddin dan Mahmud (2015), menunjukkan bahwa penggunaan video menimbulkan motivasi dan menyenangkan bagi peserta didik, yang pada akhirnya dapat menimbulkan kegairahan peserta didik dalam belajar dan menaikkan prestasi belajarnya. Dan pembelajaran akan menjadi mudah bagi peserta didik untuk menerima materi pelajaran dengan menggunakan video pembelajaran.

Media sangat memegang peranan penting dalam proses belajar mengajar. Media adalah sebuah alat untuk memproses informasi dan komunikasi yang dihubungkan dengan jaringan, media yang menarik dan atraktif dan interaktif. Melalui media potensi indra peserta didik dapat diakomodasikan sehingga kadar hasil belajar akan meningkat. Media juga dapat mempelancar pemahaman dam memperkuat ingatan selain itu, juga dapat menumbuhkan minat siswa dan dapat memberikan hubungan antara materi pelajaran dengan dunia nyata. Media dapat memotivasi dan menarik perhatian siswa untuk belajar dengan demikian media dapat diartikan suatu alat pembelajaran yang hanya bisa dilihat dengan menggunakan panca indra (Harahap, 2016).

Video yang berkaitan dengan makhluk hidup dapat dijadikan sebagai sumber belajar kedua setelah buku teks. Sumber belajar kedua ini perlu diolah dan ditata ulang menjadi media pembelajaran yang fungsional, yang menjadikan mahasiswa dapat belajar melakukan penafsiran antara fakta dan konsep yang relevan. Upaya pemanfaatan media pembelajaran memungkinkan munculnya aktivitas belajar penafsiran yang menjembatani antara fakta dan konsep ilmu yang dipelajari (Jayati, 2015).

Video pembelajaran materi kultur sel hewan dalam bentuk $C D$ pembelajaran ini mempermudah mahasiswa memahami substansi biologi yang bersifat abstrak, memiliki daya tarik untuk dipelajari, serta dapat memotivasi mahasiswa untuk lebih memahami secara lebih dalam materi kultur sel hewan (Nurcahyo, 2004). Konsep pembelajarn yang cocok digunakan oleh siswa adalah video yang memuat detil langkah-langkah teknis yang disertai dengan narasi yang jelas (Revi $d k k$, 2004). 
Pembelajaran berbasis masalah (PBL) ini dapat mendukung siswa belajar mandiri di luar kelas dan tidak terbatas oleh waktu sehingga siswa bisa belajar kapan dan di mana saja. Selain itu pembelajaran berbasis masalah juga cukup menarik tidak membuat siswa cepat bosan dalam mempelajari materi Biologi. Akhirnya pembelajaran berbasis masalah ini dapat mendukung siswa dalam mendapatkan kelengkapan data yang dibutuhkan. Sedangkan video pembelajaran yang ada cukup mempermudah siswa dalam memahami materi (Pujadi dan Harisno, 2013). Metode pembelajaran berbasis masalah dapat memberikan visualisasi materi abstrak, membantu mahasiswa belajar tanpa dibatasi ruang dan waktu, dapat menggunakan berbagai media pembelajaran sehingga materi presentasi lebih interaktif, dan membantu mahasiswa dalam pemahaman materi yang lebih dalam (Rasim $d k k, 2008)$.

\section{KESIMPULAN}

Berdasarkan hasil penelitian dan pembahasan maka dapat disimpulkan bahwa (1) Video pembelajaran kultur jaringan berbasis masalah berdasarkan hasil penilaian uji coba teman sejawat dosen termasuk dalam kriteria "layak" dengan persentase rata-rata skor yaitu $76,7 \%$, (2) Video pembelajaran kultur jaringan berbasis masalah berdasarkan hasil penilaian uji coba perorangan oleh mahasiswa termasuk dalam kriteria "layak" dengan persentase ratarata skor yaitu 75,6\%, (3) Video pembelajaran kultur jaringan berbasis masalah berdasarkan hasil penilaian uji coba kelompok kecil oleh mahasiswa termasuk dalam kriteria "cukup layak" dengan persentase rata-rata skor yaitu $73,8 \%$, (4) Video pembelajaran kultur jaringan berbasis masalah berdasarkan hasil penilaian uji coba lapangan terbatas oleh mahasiswa termasuk dalam kriteria "layak" dengan persentase rata-rata skor yaitu $82 \%$, (5) Produk video pembelajaran kultur jaringan berbasis masalah termasuk baik dan "layak" digunakan untuk perkuliahan kultur jaringan di Program Studi Pendidikan Biologi UMTS.

\section{DAFTAR PUSTAKA}

Batubara, M. S. 2016. Pengembangan Video Pembelajaran Mata Kuliah Kultur Jaringan Berbasis Masalah. Seminar Nasional II \& Workshop Biologi dan Pembelajarannya. First Postgraduate Bio Expo 2016 Universitas Negeri Medan.

Harahap. A. F. 2016. Upaya Meningkatkan Kreativitas Belajar Ilmu Pengetahuan Alam (IPA) Melalui Penerapan Model Pembelajaran Kooperatif Tipe Think Pair Share (TPS) Berbantuan Media Komputer. Jurnal EKSAKTA. $1(1): 26-32$

Harahap, F. 2011. Kultur Jaringan Tanaman. Medan: UNIMED Press.

Hasruddin dan Mahmud. 2015. Efektivitas Pengembangan Media Linier Plus Video pada Pembelajaran Mikrobiologi Terapan. Jurnal Tabularasa PPS UNIMED. 12 (3) : 320-327.

Jayati, R. D. 2015. Media Pembelajaran Anatomi Berbasis Eksternal Representasi. Prosiding Seminar Nasional dan Lomba Media Pembelajaran Lubuklinggau. Seri I.

Lubis, J. A. 2012. Pengaruh Penerapan Metode Pembelajaran Problem Solving Menggunakan Video Pembelajaran dan Camtasia Terhadap Hasil Belajar dan Kemampuan Berpikir Kritis Mahasiswa tentang Kultur Jaringan di Universitas Muhammadiyah Tapanuli Selatan. Tesis. Medan: Program Pasca Sarjana Universitas Negeri Medan.

Nurcahyo, H. 2004. Model Pengembangan Kompetensi Mahasiswa Calon Guru dalam Mengajar Bioteknologi dengan Mengoptimalkan Pemanfaatan Media Pembelajaran Berbasis Komputer. JPMS. 4 (1) : 36-43.

Pujadi, T. dan Harisno. 2013. Pengembangan Model Perangkat Ajar Berbasis Animasi: Studi Kasus Mata Ajar Biologi pada SMP Yaspia dan SMK Bina Manajemen Cakung Jakarta Timur. ComTech. Vol. 4 (1) : 363-370.

Rasim, W. Setiawan, dan E. F. Rahman. 2008. Metodologi Pembelajaran Berbasis Komputer dalam Upaya Menciptakan Kultur Pembelajaran Berbasis Teknologi Informasi dan Komunikasi. Jurnal Pendidikan Teknologi Informasi dan Komunikasi. Vol. 1 (2) : 1-17.

Revi, Syahwani, dan Dede. 2004. Pengembangan Media Tutorial dalam Pembelajaran Komputer untuk Keterampilan Membuat Server di SMK. JSM STMIK Mikroskil. Vol. 13 (2) : 149-15 